\title{
Characterization of Heavy-Metal Contamination in Surface Sediments of the Minho River Estuary by way of Factor Analysis
}

\author{
M. Mil-Homens • A. M. Costa - S. Fonseca • \\ M. A. Trancoso - C. Lopes • R. Serrano • \\ R. Sousa
}

Received: 26 July 2012/ Accepted: 11 December 2012

(c) Springer Science+Business Media New York 2013

\begin{abstract}
Surface sediments were collected in August 2009 from 49 sites along the Minho estuary (between Tui and Caminha) and analyzed for grain size, organic carbon $\left(\mathrm{C}_{\mathrm{org}}\right)$ and total nitrogen $\left(\mathrm{N}_{\mathrm{tot}}\right)$ contents, and major (silicon [Si], aluminum $[\mathrm{Al}]$, iron $[\mathrm{Fe}]$, calcium $[\mathrm{Ca}]$, magnesium $[\mathrm{Mg}]$, sodium [Na], potassium [K], titanium [Ti], and mangesese $[\mathrm{Mn}]$ ) and trace element (arsenic [As], chromium $[\mathrm{Cr}]$, copper $[\mathrm{Cu}]$, mercury $[\mathrm{Hg}]$, lithium $[\mathrm{Li}]$, lead $[\mathrm{Pb}]$, rubidium $[\mathrm{Rb}]$, tin [Sn], and zinc [Zn]) concentrations. Factor analysis was used to decrease 22 selected variables into 4 factors accounting for $85.9 \%$ of the total variance explained,
\end{abstract}

Electronic supplementary material The online version of this article (doi:10.1007/s00244-012-9861-5) contains supplementary material, which is available to authorized users.

M. Mil-Homens $(\bowtie) \cdot$ C. Lopes

Instituto Português do Mar e da Atmosfera, I.P., Av. Brasília, 1449-006 Lisbon, Portugal

e-mail: mario.milhomens@ipma.pt

M. Mil-Homens · A. M. Costa - C. Lopes

Laboratório Nacional de Energia e Geologia, I.P.,

Unidade de Geologia Marinha, Estrada da Portela,

Apartado 7586, 2721-866 Alfragide, Portugal

A. M. Costa

Arqueociências, DGPC and LARC, CIBIO/InBIO, Rua da Bica

do Marquês. $\mathrm{N}^{\circ}$ 2, 1300-087 Lisbon, Portugal

S. Fonseca $\cdot$ R. Serrano

Laboratório de Referência do Ambiente, Núcleo Operacional de Química Inorgânica, Agência Portuguesa do Ambiente,

I.P., Rua da Murgueira, 9-9A, Zambujal, Apartado 7585,

2611-865 Amadora, Portugal

M. A. Trancoso - R. Sousa

Laboratório de Biocombustíveis e Ambiente, Laboratório

Nacional de Energia e Geologia, I.P., Azinhaga dos Lameiros,

1649-038 Lisbon, Portugal suggesting distinct elemental sources or sediment components affecting their spatial distributions. Although factors 1 (detrital component; elements strongly associated with fine[Na, Mg, Ti, Li, Cr, Cu, Fe, Al, Zn, Ca, and As] and coarsegrained sediments [ $\mathrm{Si}, \mathrm{K}, \mathrm{Rb}$; mean grain-size $\left[\mathrm{M}_{\mathrm{GS}}\right]$ ) and 3 (Fe-Mn oxyhydroxide sediment component; Fe, Mn, As, fine fraction) are interpreted as reflecting predominance of natural contributions, factors 2 (urban and industrial contamination: sediment components $[\mathrm{Pb}, \mathrm{Hg}$, organic carbon $\left[\mathrm{C}_{\text {org }}\right]$, total nitrogen $\left[\mathrm{N}_{\text {tot }}\right]$ and 4 (components associated with contamination by nautical activities; the association of tin $[\mathrm{Sn}]$ and calcium [Ca]) seem to indicate anthropogenic contributions). Nevertheless, the influence of elemental contributions derived from tungsten (W)-Sn mineralizations and those resulting from mining activities can also contribute to the obtained geochemical associations and should be considered. Spatial distribution of dominant factor scores shows the dominance of factors 2 and 4 between Tui and Vila Nova de Cerveira, whereas samples dominated by factors 3 and 1 are found between Ilha da Boega and Seixas and in the Caminha areas, respectively. Despite the dominance of factor score 1 in the Caminha area, the distribution pattern of dominant factor scores shows samples dominated by other factor scores that can be explained by dredging activities in this river sector that restore ancient sedimentary characteristics or expose contaminated sediments. Through the identification of sample locations dominated by factors associated with contamination, it will be possible to select them as priority areas where new environmental (e.g., toxicity tests, organic Sn compounds, tracers of sewage contamination) studies should be implemented in the future.

Sediments represent an important component of aquatic environments, providing environmental conditions for the 